\title{
A MIGRÁCIÓ TÉMÁJÁNAK TANÍTÁSA - ÖSSZEHASONLÍTÓ TANKÖNYVELEMZÉS MAGYARORSZÁG ÉS ANGLIA TANKÖNYVEINEK PÉLDÁJÁN
}

Teaching the topic of migration - Comparative analysis on the example of textbooks in Hungary and England

\author{
VARJAS JÁNOS ${ }^{\mathrm{a}, \mathrm{d}}$ - KUTYIFA KINGA ${ }^{\mathrm{b}, \mathrm{e}}$ - SZALAI EMESE RÓZSAc,f

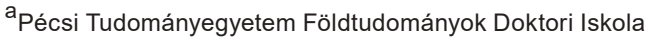 \\ ${ }^{b}$ Cserepka János Magyar-Angol Két Tanítási Nyelvű Baptista Általános Iskola, Gimnázium, Sportiskola, Technikum, \\ Szakgimnázium és Szakképző Iskola \\ ${ }^{\mathrm{C}}$ Pécsi Tudományegyetem Természettudományi Kar \\ dvjanos@gamma.ttk.pte.hu, ${ }^{e}$ kutyifa.kinga@cserepkasuli.hu, femmarozsa@gmail.com
}

\section{ABSTRACT}

Migration is one of the main challenges of the 21st century. It is a complex and diverse topic with economic, social, and climate change aspects, among others. From a social point of view, it is crucial to highlight the educational aspects of the topic, as a significant proportion of immigrants are integrated through public education. Although there are many good practices related to the education of immigrants, the teaching of the phenomenon of migration itself within the subject of geography has been less emphasized in previous research. Our study aims to assess the role of textbooks in Hungarian and English geography in connection with the teaching of migration.

Keywords: geography education, migration, comparative textbook analysis, Hungary, England

\section{BEVEZETŐ}

A különböző tudományterületek a migráció fogalmi rendszerét más és más megközelítésből vizsgálják. A társadalomtudományok közül a történelem, a néprajz és a régészet történeti szempontjait elemzi (például Manning, P. 2012). A szociológia és a társadalomtudomány, valamint a regionális tudományok a kurrens migrációs trendek elemzésével foglalkoznak. A földrajz tudományának feladata a migráció kapcsán jelentős, hiszen láthatóan rendkívül komplex, a földrajzi térben történő problémakörről van szó, ami igényli a szintetizáló, interdiszciplináris megértést (PIRISI G. - TrócsáNY I A. 2019). A földrajz az iskolában is szintetizáló tantárgyként jelenik meg, amely híd szerepet tölt be a természet és társadalom megértésével foglalkozó tantárgyak között, így a migráció 
társadalmi és politikai vitát generáló (JANKY B. 2016), elöítéletekhez vezető (GöRBE A.-NÉ ZÁm K. 2014) tematikájának tanítása kapcsán kitüntetett szerepet tölthet be. Tanulmányunkban e feladat teljesülésének vizsgálatát végeztük el magyar és angol, közoktatásban használt földrajztankönyvek felhasználásával.

Az összehasonlító vizsgálat megkezdésekor az volt az elözetes feltételezésünk, hogy a magyarországi könyvek a földrajz hagyományos belső felosztását (természet- és társadalomföldrajz) erősebben megőrizve - összehasonlítva az angol tankönyvekkel - kevésbé alkalmasak a migráció kapcsán komplex kép kialakítására, ugyanakkor a természettudományos megismerés módszertanára építve nagyobb súlyt helyeznek a diákok feladatorientált képességfejlesztésére. Az angol tankönyvek a magyar tankönyvek felfogásától eltérően inkább az érzékenyítésre, az empatikus viselkedés fejlesztésére koncentrálnak, annak érdekében, hogy biztosítsák a multikulturális társadalom jövőjét. Ennek fö oka, hogy Anglia történeti fejlődéséből adódóan hagyományosan befogadó ország (HANSEN, R. 2000), bevándorló gyökerekkel rendelkező lakosságának aránya pedig folyamatosan növekszik (OFNS 2011), míg Magyarország a jelenlegi nemzetközi migrációs áramlatokban fóként tranzitország szerepet játszik (FLEISCHER T. 2017). Eddigi tapasztalataink, illetve a két ország nemzeti tanterveinek (EEM 2012, 2020a; DFE 2014a) és földrajz kerettanterveinek (EEM 2013; 2020b; 2020c; DFE 2014b; 2014c) összehasonlítása alapján feltételeztük továbbá, hogy a magyarországi tankönyvek a tényszerü ismeretek tekintetében nagyobb mennyiségü tudás átadására vállalkoznak.

\section{KUTATÁSI ELŐZMÉNYEK}

Ahhoz, hogy megvizsgáljuk, a földrajz tantárgy képes-e teljesíteni a migráció tanításában betöltött feladatát, érdemes az iskolában továbbra is fontos szerephez jutó iskolai földrajztankönyveket (Jongwon, L. - CATLing, S. 2015) elemezni. A tankönyvek teremtik meg a tervezett és az alkalmazott tanterv közötti kapcsolatot, feladatuk a tantervek által kijelölt célokat és szándékot alkalmazni, potenciálisan megvalósítani az iskolai gyakorlatban (VAlverde, G. A. et al. 2002). Meghatározó információk és ismeretek (KoJAnitz L. 2007a), valamint társadalmi koncepciók közvetítését végzik (VINDEvoGHeL, L. J. 2016), emellett a migráció erősen vitatott témája kapcsán különösen kiemelendő, hogy rejtett információátadó szerepük is van (Sсотт, D. - LAwson, H. 2002). Ezek ellenére a földrajz tantárgy, illetve a földrajztankönyvek elemzése a migráció fogalomköre szempontjából a nemzetközi szakirodalomban - néhány kivételtől eltekintve - még nem kutatott terület.

Egy UNESCO által vezetett vizsgálat (2019) tizenkettő, föleg a migrációban fontos szerepet betöltő (küldő vagy fogadó) ország korábban és jelenleg érvényben lévő oktatási 
dokumentumait (föleg tanterveket, iskolai segédanyagokat, és - ahol lehetséges volt - tankönyveket) elemezte annak érdekében, hogy világszinten mérje fel a migráció fogalmi rendszerének megjelenését az iskolában. A kutatásban az Egyesült Királyságból származó oktatásszabályozó dokumentumokat is értékelték, de angol tankönyvek nem kerültek elemzésre. Ausztriában (Hintermann, C. et al. 2014) és a Dél-afrikai Köztársaságban (CHisholm, L. 2008) zajlottak vizsgálódások a migráció kapcsán a történelemtankönyvek alapján. E tanulmányok célja a migrációval kapcsolatos előítéletek, illetve a megjelenő rasszizmus feltárása volt, történeti összefüggésben, a 20. század második felének könyveit felhasználva. Ezek a kutatások megmutatták, a migráció folyamatának iskolai megismerése elengedhetetlen, fontos része az állampolgári nevelésnek (például BAnks, J. A. 2017), valamint, ahogy Esteves, M. (2015) portugál tanárokkal végzett kérdőíves kutatása is rámutat, az egyik legfontosabb témája a földrajz tantárgy állampolgári neveléshez kapcsolt feladatainak is. A földrajznak a témában betöltött szerepével kapcsolatban SARNO, E. (2011) olasz egyetemeken zajló, a migráció folyamatára felfüzött, kutatásalapú tanártovábbképzések tapasztalatait mutatja be. Cikkének végső következtetésében kifejti, hogy a megfelelően alkalmazott módszerekkel megváltozhat a diákok migrációhoz, migránsokhoz köthető attitűdje.

\section{KUTATÁSI MÓDSZEREK}

\section{Kvantitatív tankönyvelemzés}

F. DÁrdai Á. - M. CsÁszÁr Zs. (2004, 2006) módszertanát felhasználva a kvantitatív tankönyvelemzés során a migrációhoz köthető fogalmak megjelenési arányait vizsgáltuk a teljes szöveghez viszonyítva. Ezt követően a migrációhoz köthető szövegrészeket kategorizáltuk a fogalmak megjelenési helye - az alapszövegben vagy módszertani eszköztár valamely más elemében - alapján. Az alapszöveget tanulhatósági szempontból értékeltük, felhasználva KojAnitz L. (2007a) módszertani tanácsait. A módszertani eszköztárat mennyiségi paraméterek (az eszközöknek a törzsszöveghez viszonyított aránya, az eszközök típusai, a típusok arányai a könyvekben) alapján vizsgáltuk, emellett mindkét ország könyveivel kapcsolatban felmértük, hogy a módszertani eszköztár mennyi segítséget nyújt a tanuláshoz. Ehhez F. DÁrdai Á. (2001), Kojanitz L. (2003) és JANкo, T. - KNeCKT, P. (2013) munkáiban bemutatott módszereket alkalmaztuk. Vizsgáltuk a képek és ábrát méretét, minőségét, illetve a hozzájuk tartozó feliratokat.

A modern tankönyvekben egyre nagyobb súlyt helyeznek a feladatokra, így ezeket a módszertani eszköztár többi elemétől elkülönítve is vizsgáltuk. YANG, D. et al. (2015) módszertanát alkalmazva, akik kínai tankönyvek feladatait elemezték az oktatási reform 
előtt és után, a migráció témájához köthető feladatokat a bloomi taxonómia kognitív (Bloom, B. S. 1956) és affektív (KRAтнwohl, D. R. et al. 1964) szintjein helyeztük el.

\section{Kvalitatív tankönyvelemzés}

A tankönyv tartalmának mélyebb megértéséhez F. DÁrdAI Á. - M. CsászÁr Zs. (2004 és 2006) tanulmányainak módszertani elvei alapján tematikai súlypontokat alakítottunk ki. Ezeket az 1. ábra mutatja be. Az egységek létrehozásakor a kvantitatív analízis tapasztalatait felhasználva fő szempontunk az volt, hogy ennek a komplex és rendkívül szerteágazó problémakörnek a megjelenését minél részletesebben értelmezzük. Külön értékeltük azt, hogy a diákok számára a tankönyvek bemutatják-e a vándorlást beindító mozgatórugókat, és mennyire széleskörüen ábrázolnak olyan kiváltó okokat, mint például a helyi konfliktusok, az éghajlatváltozás okozta elvándorlás (klímamigráció) vagy a gazdasági mozgatórugók.

A kvantitatív vizsgálatok eredményei és a témával foglalkozó szakirodalom (például PIRISI G. - TRócsáNYI A. 2019) alapján a migrációs áramlatok folyamatainak elemzését két csoportra bontva tettük meg. A kivándorlást kiváló okok után a belső vándorláshoz köthető tankönyvi tartalmakat vizsgáltuk. Ebben a csoportban elemeztük az adott ország (Magyarország, illetve Anglia) történeti és kurrens belső vándorlásaihoz kapcsolt tartalmakat, illetve egyéb országok, például Oroszország urbanizációs folyamatait.

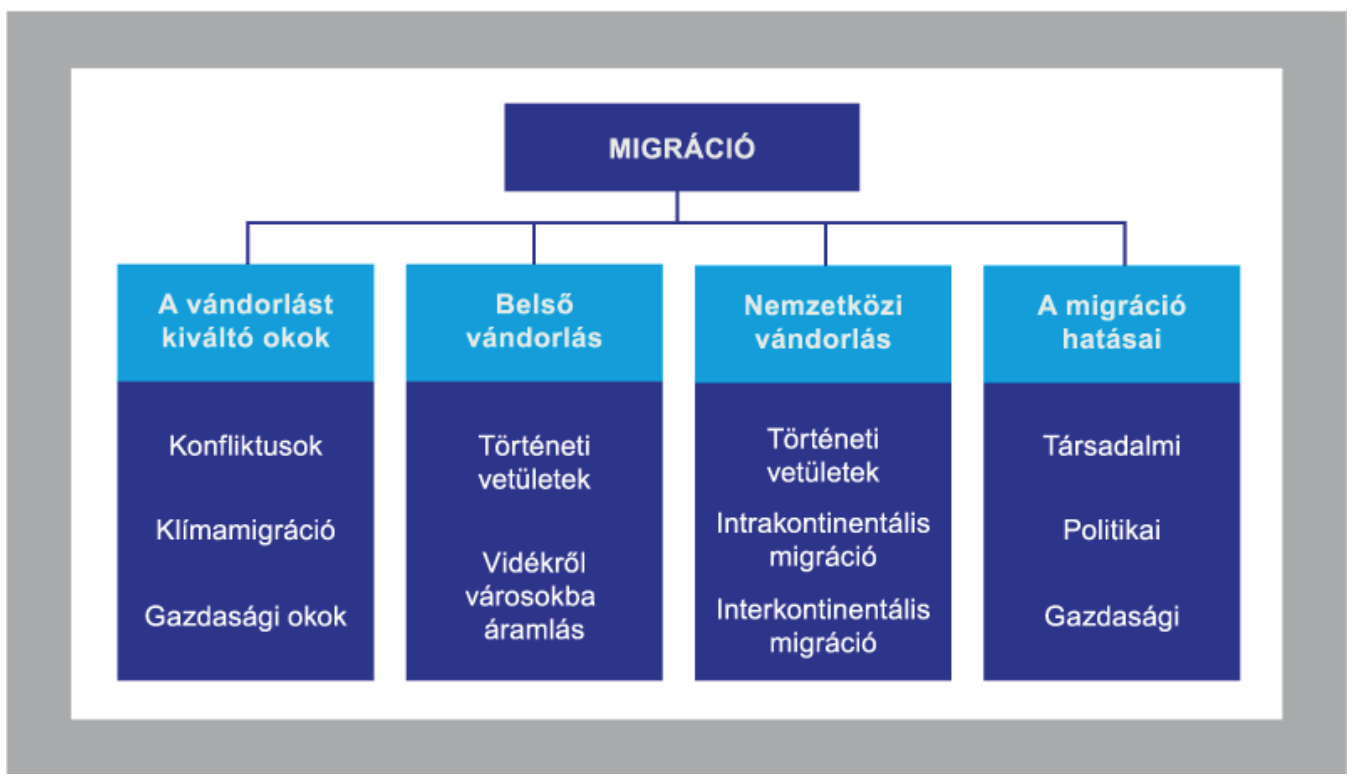

1. ábra. A súlypontelemzés csoportjai 
A következő tematikai egységként a nemzetközi - határokon átlépő - vándorlás megjelenésének bemutatását vizsgáltuk. Külön elemeztük a nagyobb számban megjelenő témákat, mint például az Európába vagy az Amerikai Egyesült Államokba történő migráció történeti, illetve jelenlegi áramlatait. A migráció hatással van a küldő és a befogadó ország társadalmára, ami politikai változásokhoz vezethet, ezen elemek bemutatását is értékeltük. Így egy összetett folyamatot több szempontból megközelítve elemeztük.

\section{A kiválasztott tankönyvek}

A kutatás során a jelenleg használatban lévő magyarországi (AlEXA P. et al. 2018, F. KuszTor A. et al. 2018, ArdAy I. et al. 2018a, 2018b) könyveket vizsgáltuk, amelyek az általános iskola 7. osztályától a gimnázium 10. osztályáig vannak érvényben. A könyvek a 2012-es Nemzeti alaptantervhez (EEM 2012) és az ehhez tartozó földrajz kerettantervhez (EEM 2013) készültek. Emellett a 2020-ban kiadott Nemzeti alaptantervhez (EEM 2020a; EEM 2020c) készült 9. osztályos tankönyv A. (ARDAY I. et al. 2020) és B. (F. Kusztor A. - NAgY B. 2020) változatait is értékeltük.

Angliában a sokrétű tankönyvpiac miatt egyszerre több tankönyvcsalád is elérhető. Az angol nemzeti tantervhez (DFE 2014a) tartozó földrajz tanterv (DFE 2014b; 2014c) a tartalmi szabályozás (például tantárgyi müveltségi tartalom) tekintetében nem részletesen kidolgozott, így a tankönyvszerzők a magyar oktatási rendszerhez képest nagyobb szabadsággal dolgoznak (LEE, J. - CATLing, S. 2016). A jelenleg érvényben lévő könyvek kiválasztásakor a számunkra hozzáférhető, Oxford Egyetemi Kiadó tankönyvei (Gallagher, R. et al. 2014; Gallagher, R. - Parish, R. 2014a; 2014b) mellett döntöttünk.

\section{A KUTATÁSI EREDMÉNYEK BEMUTATÁSA}

\section{Kvalitatív elemzés}

\section{Magyar tankönyvek}

A négyéves magyar földrajzi tanulmányok során minden tankönyvben elökerül a migráció témája, de eltérő arányokkal. A könyvekben található leckék számát figyelembe véve legnagyobb arányban a nyolcadikosok találkoznak a migráció témájával (4\%). Alacsonyabb említési arányokkal találkozhatunk a 7. és a 9. osztály könyveiben, ahol nincs jelen önálló leckeként. Ennek oka a tantárgy belső szerkezete. A 7. és a 9. 
osztályos tananyag föleg a természetföldrajzra koncentrál a tankönyvek számára alapul szolgáló 2012-es földrajz kerettantervekben. Önálló leckében 8. osztályban (Európa társadalmi és gazdasági képe; Népességmozgások hazánkban), valamint 10. osztályban leckerészként (Urbanizációs problémák; Népesedési folyamatok hatása) találkozhatunk vele. A tantárgy belső felosztása a 2020 -as Nemzeti alaptantervhez tartozó földrajz kerettantervben jelentős változásokon ment át. A legújabb 9. osztályos tankönyvben az általános természet- és társadalomföldrajzzal foglalkozó fejezetek egymás mellett kerülnek tárgyalásra. Előzetes feltételezésünk az volt, hogy a migráció fogalmi rendszere főként az alapszövegben jelenik meg a magyar könyvekben, és ez be is igazolódott. A főszöveg értékeléskor kiderült, hogy mondatai szakkifejezésekkel telítettek, a tulajdonnevek (beazonosításra váró földrajzi nevek) száma is magas. A tanulást megkönnyítendő a fontos kifejezések félkövér betütípussal jelennek meg.

$\mathrm{Az}$ összes elemzett tankönyvbe 156 helyen történik meg a migráció említése. Legnagyobb arányban (43\%-ban) feladatokban találkozhatunk vele (2. ábra). A kiegészítő szövegek száma is magas, így a migráció ebben az apparátuselemben fedezhető fel a második legnagyobb (24\%-os) arányban. A kiegészítő szövegek szürke mezőben jelennek meg az újgenerációs könyvben, jól elkülönítve azokat a megtanulandó szövegrészektől. A 2020-ban kiadott tankönyvekben a kiegészítő szövegek aránya jelentősen visszaszorult. Kevesebb ábrát, képet és táblázatot találunk, viszont a téma több vetületére is láthatunk magyarázó példát. Megjelenik a belső vándorlás (például OFI 10. p. 182.), a kontinensek közötti vándorlás (például az OFI 8. p. 67.) és az interkontinentális vándorlással (például OFI 8. p. 66.) kapcsolatban is van értelmező eszköz. A 2020-as tankönyvek B változatában a legmagasabb (5 darab) a migrációhoz köthető képek száma.

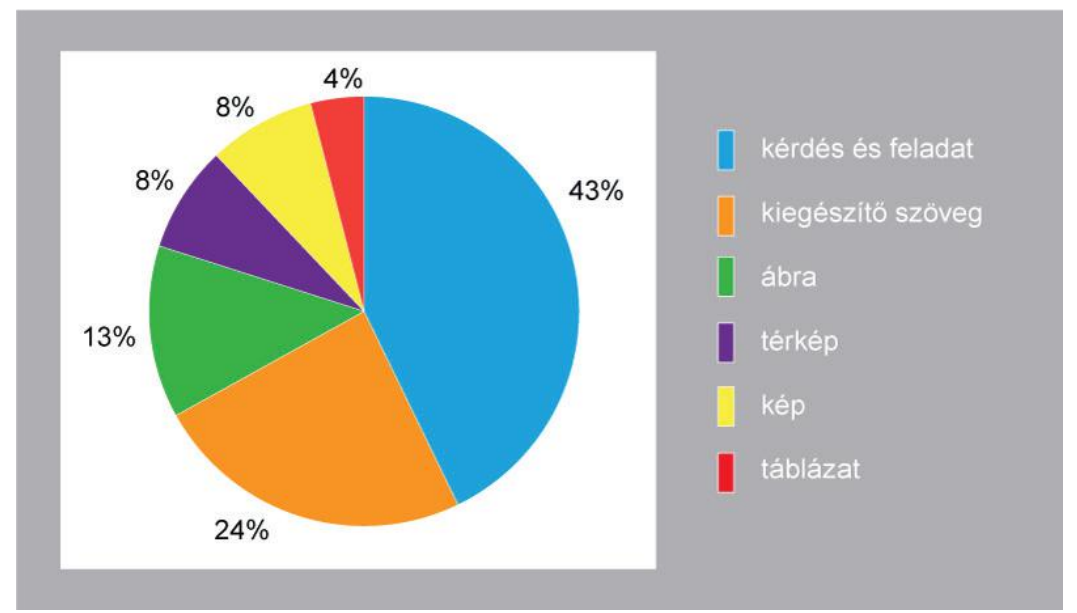

2. ábra. A migráció témájának megjelenése a magyar könyvek módszertani eszköztárában 
A módszertani eszköztár megfelelő méretű és felbontású elemeket tartalmaz, amelyek segítik a tanulást. Az ábrák elhelyezése, kialakítása és színezése egységes, jól elkülönülnek az alapszövegtől. Az elemekhez tartozó feliratok világosan kifejtik az elemek tartalmát. Szoros kapcsolatban állnak a föszöveggel, gyakran idézik is azt. Ezenfelül új tartalmakat, új értelmezéseket és kifejtett információkat adnak az alapszöveghez. A térképek egy-egy leckén belül is egymásra épülhetnek. Erre jó példa a Fogyunk, öregszünk, vándorlunk címü leckének a vándorláshoz köthető három térképe a 66-67. oldalakon.

A tankönyvek didaktikai elemeihez - kevés kivételtől eltekintve, például OFI 10. p. 93. - minden alkalommal rendeltek feladatot. Az új információk feladatokkal történő megismerése a tudás mélyebb elraktározását segíti. A legtöbb feladat elemzést igényel, az összes feladat (50 darab) 28\%-a analitikus gondolkodást igénylő műveleteket kér. Emellett több példát is találunk arra, hogy a tankönyvi leckékben egymásra épülő, eltérő kognitív szintet igénylő feladatok vannak (például a 139. oldalon a menekültválsággal foglalkozó térkép). A könyv a komplex és vitaindító témát kihasználva többször épít a diákok önálló véleményalkotására és értékítéletére (például OFI 10. p. 139.), a témával kapcsolatban véleményvonal alkotását is kéri a diákoktól (OFI 9. p. 132.). A többszintü feladatok alkalmazása végigvezeti a tanulókat a témán, és segíti az ok-okozati kapcsolódások mély megértését. A feladatokra mutat példákat az 1. táblázat.

\section{Angol tankönyvek}

Angliában a földrajz tanulása kötelező az iskola Key Stage (kulcsszakasz, továbbiakban KS) 1., 2. és 3. szintjein. A diákok így 5-7 éves koruktól egészen a 9. oktatási évükig, 14 éves korukig foglalkoznak iskolai földrajzzal (DfE 2014a; 2014b; 2014c). Az általunk elemzett könyvek a KS 3. szintre készültek, azaz 11 és 14 éves kor között tanulnak belöle az angol diákok. A migráció legnagyobb hangsúlyt a Geog. 1 könyvben kap, itt a leckék számához viszonyítva 5\%-ban van jelen a téma. A 144 oldalas tankönyv 19 oldalán fordul elö a migrációhoz köthető tartalom. A másik két könyvben (Geog. 2. és Geog. 3.) a leckéknek megközelítőleg 2\%-a köthető a migrációhoz. A Geog. 1. könyvben 10 oldalon (teljes oldalszám 144), míg a Geog. 3-ban 9 oldalon (teljes oldalszám 144) találkozhatunk népességvándorláshoz köthető tartalommal.

Önállóan kerül tárgyalásra a migrációhoz köthető téma a Geog. 1. könyv Life as a nomad címü leckéjében. Ez a lecke a Horn of Africa fejezet része, amely Kelet-Afrikával foglalkozik. A diákok a Geog. 2. könyv Why people move to urban areas? leckéjében több személy látószögén keresztül ismerhetik meg a faluból városba történő, országon belüli migrációs folyamatokat. A Geog. 2. könyv Life in Chongqing és Tibet, valamint az ezt követő All change in Tibet lecke is részben az urbanizációs folyamatokkal és a 


\begin{tabular}{|c|c|}
\hline Tanulás kimeneti szintje & Példa a magyar tankönyvekböl \\
\hline \multicolumn{2}{|c|}{ Kognitív szintekhez kapcsolódó feladatok } \\
\hline Ismeret & $\begin{array}{l}\text { Melyek a városokba áramlás mozgatóerői, taszító és vonzó tényezői? } \\
\text { (OFI 10. p. 234.) }\end{array}$ \\
\hline Megértés & $\begin{array}{l}\text { Miért költöznek a bevándorlók elsősorban nagyobb városokba? (OFI } \\
\text { 10. p. 39.) }\end{array}$ \\
\hline Alkalmazás & $\begin{array}{l}\text { Milyen intézkedésekkel lehetne könnyíteni a bevándorlók beilleszkedé- } \\
\text { sét? Mondjatok ötleteket! (OFI 8. p. 132.) }\end{array}$ \\
\hline Analízis & $\begin{array}{l}\text { Miért áramlanak városokba az emberek? Mely tényezők segítik, és } \\
\text { melyek gátolják a folyamatot? (OFI 10. p. 39.) }\end{array}$ \\
\hline Szintézis & $\begin{array}{l}\text { A fejlett európai országok egy részében a társadalom elöregszik. Ezek } \\
\text { az országok a fejlődő világból érkező bevándorlók fö célpontjai is. Ele- } \\
\text { mezd a folyamatot a bevándorlók, a kibocsátó térség (pl. Észak-Afrika) } \\
\text { és a befogadó országok szempontjából! (OFI 10. p. 39.) }\end{array}$ \\
\hline Értékelés & $\begin{array}{l}\text { Gyűjts migrációval kapcsolatos híreket híradásokból, újságokból, az } \\
\text { internetről! Rendezd azokat irányuk szerint! (OH B. 9. p. 125.) }\end{array}$ \\
\hline \multicolumn{2}{|c|}{ Affektív szinthez kapcsolódó feladatok } \\
\hline & $\begin{array}{l}\text { Foglald össze a szemelvény alapján, hogy mi segítette és mi hátráltatta } \\
\text { az afrikai orvost a beilleszkedésben! (OFI 8. p. 67.) }\end{array}$ \\
\hline
\end{tabular}

1. táblázat. A magyar tankönyvekben megjelenö feladatok példái a bloomi taxonómia kognitív és affektív szintjein

nomadizmussal foglalkozik, de a regionális földrajzzal foglalkozó Southwest China fejezet részeként. A Geog. 3. könyvben az Európába érkező afrikai migrációval foglalkozik az Escaping from poverty (Menekülés a szegénységből) lecke, amely az International development (Nemzetközi fejlődés) fejezet része. Ez a fejezet a fejlett és a fejlődő országok között kialakult gazdasági különbségeket mutatja be a diákoknak.

Hasonlóan a magyar könyvekhez, az angol tankönyvekben is az alapszövegben találkozhatunk a migráció témájával nagyobb arányban. A tankönyvi alapszöveg azonban az angliai könyveknél nehezebben választható el az eszközkészlet többi elemétől. Gyakran az alapszöveg rövidebb mondatokban, vagy akár felsorolásos formában jelenik meg, jóval kevesebb megtanulandó fogalommal és nehezen érthető kifejezéssel. Ez könnyebben tanulhatóvá teszi, mint a magyar könyveket. A magyar tankönyvekhez hasonlóan a fontosabb fogalmak itt is félkövér szedéssel kerültek kiemelésre.

Az angol tankönyvek eszközkészletében 88 helyen jelenik meg a migráció valamely típusa. A legtöbb utalás a Geog. 2. könyvben történik. A magyar tankönyvekkel összehasonlítva eltérő arányokat tapasztalunk az eszközfajták eloszlásában. Az angol könyvekben nagyobb hangsúly kerül a fényképekre, ezek a migrációhoz kapcsolható apparátusnak 31\%-át teszik ki (3. ábra). 9 darab kép található a Geog. 1-ben, 13 a Geog. 2-ben és 9 a Geog. 3-ban. A tankönyvekben magas a kiegészítő szövegek aránya, így a migrációról ebben az apparátuselemben találkozunk a harmadik legnagyobb (22\%-os) arányban. Az 


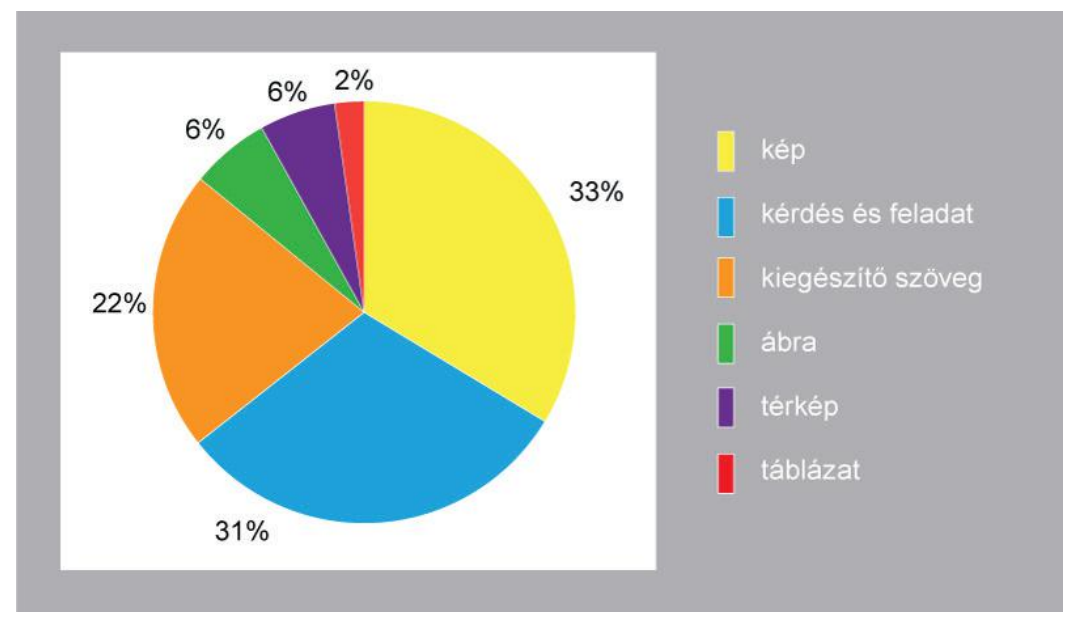

3. ábra. A migráció témájának megjelenése az angol tankönyvek didaktikai eszközkészletében

eltérő arányok eltérő tanítási megközelítésről adnak tanúbizonyságot. Míg a magyar tankönyv feladatokban és kiegészítő szövegekben ad többletinformációt a migráció témájáról, addig az angol könyvek gyakran mutatnak be fényképeket, láthatunk például nomádokat (például Geog. 1. p. 14., Geog. 3. p. 132.), illetve a Geog. 3. 80-81. oldalán található Escaping poverty lecke képeken keresztül meséli egy bevándorló fiú életét. Láthatóan nagyobb súly helyeződik a fényképekkel történő attitüdformálásra.

$\mathrm{Az}$ angol könyvek ábráinak és képeinek felirata kevés alkalommal tartalmaz feladatot, azok inkább kiegészítik az alapszöveget. Ennek ellenére a migrációhoz kapcsolt eszközök 31\%-a feladat, de a feladatok száma csökken a Geog. 3. könyvben. A Geog. 1. könyv 13 feladatot, míg a Geog. 3. már csak 5 feladatot tartalmaz a témában. A feladatok az összefoglaló részben (a Your turn mezőben) jelennek meg. Itt gyakran utalnak a lecke ábráira, grafikonjaira és térképeire is. A magyar könyvekkel szemben összeségében kevesebb a feladat, kevésbé találunk komplex szemléletmódot igénylő, témát szintetizáló, önálló kutatást igénylő feladatokat. Legnagyobb arányban tudásalkalmazást kérnek a tankönyvek a diákoktól, valamint több példát is látunk arra, hogy a leckékben egymásra épülnek az eltérő kognitív szintet igénylő feladatok (Geog. 3. p. 81.). Feladatokra láthatunk példákat a 2. táblázatban.

Az angol nemzet tanterv (DfE 2014a) két kompetencia fejlesztését jelöli meg, amelynek minden iskolai tantárgyban érvényesülnie kell. A numeracy kompetencia a számolási és logikai képességeket, míg a literacy az írott szövegek megértési és felhasználási képességeit jelenti. A földrajztankönyvekben ezért a feladatokat tartalmazó Your turn mezőben piktogrammal jelölik, hogy az adott feladatok mely terület fejlesztésében segítenek. Ez a jelzés a tanárok, illetve a diákok számára is egy visszajelzés arról, hogy 


\begin{tabular}{|c|c|}
\hline Tanulás kimeneti szintje & Példa az angol tankönyvekből \\
\hline \multicolumn{2}{|c|}{ Kognitív szintekhez kapcsolódó feladatok } \\
\hline Ismeret & $\begin{array}{l}\text { Magyarázd meg a fogalmakat. 1. bevándorló; 2. gazdasági bevándorló; } \\
\text { 3. menekült; 4. engedély nélkül az országba érkező (Geog. 3. p. 81.) }\end{array}$ \\
\hline Megértés & Miért válnak nomáddá az emberek? (Geog. 1. p. 127.) \\
\hline Alkalmazás & $\begin{array}{l}\text { Seydou melyik csoportba tartozik? (Geog. 1. p. 81. 1. feladathoz kap- } \\
\text { csolva) }\end{array}$ \\
\hline Analízis & $\begin{array}{l}\text { Oroszország európai részében rengeteg kis falu található - de közülük } \\
\text { sok hanyatlik. Mondj három indokot, hogy miért akarnak az emberek a } \\
\text { városokba költözni! (Geog.1. p. 117.) }\end{array}$ \\
\hline Szintézis & $\begin{array}{l}\text { Mi történne, ha minden nomád eldöntené, hogy letelepedik? Lássuk, } \\
\text { hány következményt tudsz megjósolni? (Jót és rosszat is) (Geog. 1. p. } \\
\text { 127.) }\end{array}$ \\
\hline Értékelés & $\begin{array}{l}\text { Nézz a képre! Îrd le, hogy mit jelent valójában a transzparensen lévő } \\
\text { szöveg! Írd le saját szavaiddal! (Geog. 3. p. 81.) }\end{array}$ \\
\hline \multicolumn{2}{|c|}{ Affektív szinthez kapcsolódó feladatok } \\
\hline & $\begin{array}{l}\text { Képzeld el, hogy nomád vagy, mint Safiyo és családja! Mik nehezítik az } \\
\text { életedet? Sorolj fel minél többet! (Geog. 1. p. 127.) }\end{array}$ \\
\hline
\end{tabular}

2. táblázat. A vizsgált angol tankönyvekben megjelenő feladatok példái a bloomi taxonómia kognitív és affektív szintjein ábrázolva

mely kompetenciáik fejlődésében léptek előre.

\section{Tematikus elemzés}

\section{A migráció kiváltó okai}

A magyarországi tankönyvek törekednek arra, hogy a migráció és annak kiváltó okai kapcsán komplex képet közvetítsenek a diákok felé. Több jelenséget is megjelölnek, melyek beindíthatják az egyéni vagy csoportos migrációs folyamatokat. A 10. osztályos könyv 38. oldalán (a Vándorló milliók cím alatt) tételesen felsorolásra kerülnek a különböző okok. Feladat segítségével reflexiót is kér a tankönyv a migráció kiváltó okai kapcsán. A fiatalabb tanulók a Fogyunk, öregszünk, vándorlunk című lecke második felében Magyarország példáján keresztül ismerkedhetnek meg migrációt eredményezö okokkal. A gazdasági migráció kapcsán láthatunk jól kidolgozott, részletes Európa térképet (OFI 8. p. 67.). A tanulmányi célú migráció is megjelenik az alapszövegben, illetve feladatban is. Kevés kivételtől eltekintve (OFI 9. pp. 206-207.) kevésbé hangsúlyozott az éghajlati okok miatti migráció. A migrációs válság és az emberiség jövőbeni vándorlása kapcsán kiemelten fontosak az éghajlati tényezők, amelyeknek a vizsgálata kapcsolatot teremthet a természet- és a társadalomföldrajz között. 
A migráció kiváltó okaival kapcsolatban az angol könyvek bemutatják a konfliktusok, etnikai problémák hatásait (Geog. 3. pp. 80-81.), történeti összefüggésben a gazdasági migráció szerepére is felhívják a figyelmet (Geog. 1. pp. 52-53.). A könyvek rámutatnak a különbségekre a különböző bevándorló kategóriák között (menekült, gazdasági bevándorló Geog. 1. p. 53. Your turn mezö). Feladatok segítségével részletesen megismerteti a könyv a szívó és a taszító tényezők hatását (Geog. 2. p. 41.) is. A migrációs válság tekintetében - szemben a magyar tankönyvvel - jobban hangsúlyozzák az országok közötti fejlettségi egyenlőtlenségek hatásait. Ezzel foglalkozik az International development címü fejezet, mely bemutatja a különbségek létrejöttét, azok hatásait (Escaping poverty lecke) és a nemzetközi fejlödés aránytalanságainak csökkentési módjait (Putting end to poverty).

\section{Belső vándorlás}

A belső vándorlás folyamatával 7. osztályban találkozunk először a magyar tankönyvekben, méghozzá az Amerikai Egyesült Államok kapcsán. Az Amerika földrajza - Korlátlan lehetőségek hazája? címü leckében kiegészítő szövegként jelennek meg az amerikai lakosság belső vándorlásának irányai. A szöveges bemutatás kevésbé alkalmas arra, hogy szemléltesse ezt. A modern belső vándorlásra további példa még Kína (OFI 7. p. 188.). A hagyományos, nomád legelőváltással és földműveléssel kapcsolatos vándorlást Afrika példáján mutatja be a könyv (OFI 7. p. 101.). Magyarország belső vándorlásáról 8. osztályban kapnak részletes képet a diákok (OFI 8. p. 66.).

$\mathrm{Az}$ angol könyvek részletesen foglalkoznak a falvakból városokba áramló lakosság problémakörével. A Why do people move? címü leckében (Geog. 2. pp. 40-41.) különböző nemzetiségű (brit, brazil, bangladesi) személyek példáját láthatjuk, akik városokba költöztek. A Life in Chongqing leckében a városba érkező, eltérő életet élő emberekkel és az általuk a falvakban hagyott gyerekekkel ismerkedhetünk meg. A magyar könyvekhez hasonlóan bemutatja a nomadizmust az afrikai lakosság példáján (Geog. 1. Life as a nomad), azonban személyesebb, emberközeli módon mutatja be egy nomád család életét és problémáit. Összességében azonban ezek a leckék a másik könyvben lévőkhöz hasonlóan épülnek fel.

\section{Nemzetközi vándorlás}

A magyar könyvek a nemzetközi vándorlás témáját történeti példák bemutatásával kezdik el bevezetni. Megismerhetjük az európai gyarmatosító országoknak az afrikai (OFI 7. p. 96.) és az amerikai kontinensen (OFI 7. p. 138., pp. 142-143.) zajlott tevékenységét. Külön figyelmet fordít a 7. osztályos tankönyv arra, hogy kiemelje a természeti 
adottságok hatásait a migrációra (OFI 7. p. 126. 2. feladat). A már említett Amerika földrajza - Korlátlan lehetőségek hazája? címü lecke az USA gazdasági nagyhatalommá válását és jelenlegi helyzetét mutatja be. Történeti áttekintés után külön cím alatt tárgyalja az amerikai lakosság etnikai összetételének alakulását a migráció hatására, az ország létrejöttétől egészen a jövőben várható bevándorlási arányokig. Hagyományos befogadó országok tekintetében, mint például az Egyesült Királyság (OFI 8. pp. 170-171.) vagy Németország (OFI 8. pp. 131-132.), szintén bemutatásra kerül a nemzetközi migráció. A tankönyvek minden kifejtett téma kapcsán kíváncsiak a diákok visszajelzésére, önálló véleményük kifejtésére. Különösen igaz ez a 2015-ös migrációs válság kapcsán, amelyet több helyen is tárgyal a tankönyv (OFI 8. p. 17., OFI 10. pp. 38-39.).

A földrajz tantárgy magyartól eltérő tudományos besorolása, illetve az Egyesült Királyság multikulturális társadalma miatt a történeti szemlélet nagyobb hangsúlylyal jelenik meg az általunk vizsgált angol tankönyvekben. Az Egyesült Királysággal foglalkozó fejezet Who are we? címü leckéje (Geog. 1. pp. 52-53.) teljes egészében egy történelmi idővonal segítségével mutatja be az országba érkezők eredetét a történelem előtti időktől napjainkig. Feladatok felhasználásával segíti a könyv a diákok számára a vándorlók egyes kategóriáinak megkülönböztetését (például gazdasági migráns, menekült) (2. táblázat). Az angol tankönyvek a nemzetközi migrációs problémák bemutatásakor az objektív vélemény kialakítását elősegítő, rendszerszintű tudás kiépítésére összpontosító magyar tankönyvekkel szemben inkább a bevándorlók életének részletesebb bemutatására helyezik a súlyt, és felhívják a diákok figyelmét a migrációs folyamatokat alakító tényezőkre. Ez tükröződik a Geog. 3. tankönyv 80-81. oldalának leckéjén, ahol egy bevándorló fiú Európába történő eljutását mutatja be a tankönyv.

\section{A migráció hatásai}

A magyar tankönyvek nagy súlyt fektetnek a migráció negatív hatásainak bemutatására. Feladatok segítségével pedig felhívják a figyelmet a migráció okozta kihívásokra, mind a küldő országok (elvándorlási arány csökkentése - OFI 10. p. 27.), mind a befogadók (például OFI 8. p. 160.) tekintetében. Természetesen ezzel szemben a pozitív hatások is megjelennek (például Magyarország kapcsán OFI 9. p. 66.), emellett, ahogyan már korábban is említettük, a könyv gyakran épít a diákok önálló véleményalkotására, tudásának alkalmazására. Ez a migráció hatásai kapcsán is kifejtésre kerül, ehhez kapcsolva a migráció tudományos fogalomrendszerének ismertetését (OFI 10. p. 93.). Önálló véleményalkotás mellett a 10. osztályos diákok táblázatos formában is láthatják a migráció hatásait (OFI 10. p. 38.). 
Az angol tankönyv történeti összefüggéseiben mutatja be a migráció hatásait (Geog. 1. pp. 52-53.), rámutatva arra, hogy az Egyesült Királyság története összeforrott a migráció jelenségével. Ehhez kapcsolódva London példáján keresztül mutatja be egy multikulturális város jellegét (Geog.1. p. 59.). A migráció hatásaival kapcsolatban fontosnak tartja a kialakult politikai és társadalmi viták bemutatását, amit megtesznek a magyar tankönyvek is (OFI 10. p. 39. 11. c) feladat), de az angol tankönyvek felhívják a figyelmet a szegénység felszámolásában való részvétel szükségességére is (Geog. 3. p. 83.).

\section{KÖVETKEZTETÉSEK}

Kutatásunk során két eltérő történeti fejlődéssel és társadalmi-politikai berendezkedéssel rendelkező ország földrajztankönyveit vizsgáltuk. Az Egyesült Királyság ma is a világ egyik legjelentősebb befogadó országa, amely nagyszámú migrációs hátterü lakossággal rendelkezik. Ennek hatására egy multikulturális társadalmi szerkezet jött létre, ezért az oktatási rendszere is a multikulturális nevelés irányába mozdult el. Ennek célja a társadalmi kohézió, illetve az inkluzív oktatás feltételeinek megteremtése. Ezzel szemben Magyarország, mely ugyan tranzitországként a jelenlegi migrációs folyamatok (például a 2015-ös európai migrációs válság) fontos szereplője, és a történeti fejlödésében jelentős szerephez jutottak a vándorlási folyamatok, jelenleg nem rendelkezik nagyobb számú bevándorló lakossággal (Eurostat 2015), ezért oktatási rendszere kisebb súlyt helyez a multietnikai nevelésre. További alakító tényező a két ország földrajztankönyvei kapcsán a földrajz tantárgy eltérő megítélése és helyzete, ugyanis Angliában a földrajztudományt a társadalomtudományokhoz sorolják. Integrált részét alkotják a természettudományokhoz kapcsolódó tartalmak is, de nagyobb súlyt fektetnek a történelmi megközelítésre.

A fentieken túl az angol tankönyvek az empatikus nevelés, illetve a kompetenciafejlesztés számára is nagyobb teret biztosítanak. Ez abban is megnyilvánul, hogy összehasonlítva a magyar tankönyvekkel, jelentősen kevesebb tényanyagot tartalmaznak. A megtanítandó tartalom mennyiségének különbsége a földrajz tantárgy oktatási szabályozásának eltérő felfogásából származik. A magyarországi kerettanterv részletesen kifejtve adja meg a földrajz tantárgy tartalmi kereteit, viszonylag nagy mennyiségü lexikális ismeret átadására törekszik, míg az angol tanterv minimális tartalmi keretet jelöl ki, kevesebb lexikális tananyag feldolgozását várja el. A kerettantervi követelmények mentén a magyar tankönyvek a tudományos megismerés módszereinek átadására nagyobb súlyt helyeznek, fontosnak tartják azt, hogy a tanulók a tankönyveken kívüli forrásokból is információt gyűjtsenek, ezek felhasználásával a migráció témája kapcsán komplex véleményt alakítsanak ki. A komplex, több szempontból történő megközelítés 
akadálya lehet azonban, hogy a magyarországi tankönyvekben még mindig erős a természet- és a társadalomföldrajzi tartalmak elkülönülése, bár ez jelentős átalakuláson megy át 2020 szeptemberétől a módosított keretantervek 9. osztályban történő bevezetésével. A változások tükröződnek a 2020-ban kiadott tankönyvek A, illetve B változatában is. A természetföldrajzzal foglalkozó fejezetek (például csillagászat, kőzetburok földrajza) után rögtön kezdődnek a társadalomföldrajzot megalapozó témák kifejtései. A természet- és a társadalomföldrajzi tartalmak egy tanévben történő tanulása segíti a komplexebb földrajzi kép megalapozását.

Mindkét ország tankönyve - eltekintve néhány kivételtől, mint például a cirkuláció (gyakran ismétlődő, két terület közötti vándorlás) jelensége - tartalmazza azokat a kereteket, információkat, amelyek szükségesek a migráció bonyolult fogalmi hálózatának megértéséhez. Jól illusztrált, a tanulók számára is motiváló könyvekről van szó, amelyek közelebb hozzák a diákokhoz az aktuálisan vizsgált témát. A vándorlás jelensége segítségével állampolgári ismereteket adnak át, ami a földrajz egyik kiemelt feladata mindkét ország esetében (Butт, G. 2011), és ezt a feladatot más tantárgyakkal együttmüködve teljesítheti (Рyкetт, J. 2009).

Tanulmányunk hiányossága lehet, hogy - mint azt korábban is említettük Angliában többszereplös, szabad tankönyvpiac müködik. Nem volt lehetőségünk arra, hogy a piacon fellelhetö összes földrajztankönyv vizsgálatát elvégezzük.

\section{IRODALOM}

BANks, J. A. (2017): Citizenship education and global migration: implications for theory, research, and teaching. - American Educational Research Association, Washington. 528 p.

Bloom, B. S. (1956): Taxonomy of educational objectives, handbook: the cognitive domain. - David McKay, New York. 207 p.

Butt, G. (2011): Geography, education and the future. - Continuum, London. 284 p.

Chisholm, L. (2008): Migration, citizenship and South African history textbooks. - South African Historical Journal 60. 3. pp. 353-374. https://doi.org/10.1080/02582470802417441

Esteves, M. (2015): Citizenship education - What geography teachers think on the subject and how they are involved? Procedia - Social and Behavioral Sciences 191. pp. 447-451. https://doi.org/10.1016/j. sbspro.2015.04.697

F. DÁrdai Á. (2001): A tankönyvek megítélésének minőségi paraméterei. - In: Karlovitz J. (szerk.): Tankönyvelméleti tanácskozás. Tankönyvesek Országos Szövetsége, Budapest. pp. 56-60.

F. DÁrdai Á. - M. CsászÁr Zs. (2004): Afrika-kép a magyar történelem- és földrajztankönyvekben. Iskolakultúra 14. 11. pp. 69-77.

F. Dárdai Á. - M. CsászÁr Zs. (2006): Magyar történelem és földrajz tankönyvek Balkán-képe. Iskolakultúra 16. 7-8. pp. 179-191. 
FLeIsCher T. (2017): A migráció és társadalmi-gazdasági összefüggései: az MTA KRTK vándorszemináriuma. - Tér és Társadalom 31. 1. pp. 147-157. https://doi.org/10.17649/TET.31.1.2834

Görbe A.-NÉ ZÁm K. (2014): Migráció - elöítélet - idegenellenesség. Előítélet-kutatás a belügyi ágazatban. - Nemzeti Közszolgálati Egyetem, Budapest. 39 p.

Hansen, R. (2000): Citizenship and immigration in postwar Britain. - Oxford University Press, Oxford. $316 \mathrm{p}$.

Hintermann, C. - Markom, C. - WeinhäUpl, H. - Üllen, S. (2014): Debating migration in textbooks and classrooms in Austria. - Journal of Educational Media, Memory, and Society 6. 1. pp. 79-106. https://doi.org/10.3167/jemms.2014.060105

JANкo, T. - Клескт, Р. (2013): Visuals in geography textbooks: categorization of types and assessment of their instructional qualities. - Review of International Geographical Education Online. 3. 1. pp. 93-111.

JANKY B. (2016): A témakeretezés hatása a menekültpolitikával kapcsolatos véleményekre. - REGIO 24. 4. pp. 121-139. https://doi.org/10.17355/rkkpt.v24i4.139

Jongwon, L. - Catling, S. (2015): Some perceptions of English geography textbook authors on writing textbooks. - International Research in Geographical and Environmental Education 25. pp. 1-18. https://doi.org/10.1080/10382046.2015.1106204

KoJanitz L. (2003): Szakiskolai tankönyvek összehasonlító vizsgálata III. Illusztrációk. - Új Pedagógiai Szemle 53. 11. pp. 77-84.

KojAnitz L. (2007a): A tankönyvek minőségének megítélése. Mi ad értelmet a tankönyvek értékelésének és kutatásának? - Iskolakultúra 17. 6-7. pp. 114-126.

KojAnitz L. (2007b): Lehet-e statisztikai eszközökkel mérni a tankönyvek minőséget? - Iskolakultúra 14. 9. pp. 38-56.

Krathwohl, D. R. - Bloom, B. S., - Masia, B. B. (1964): Taxonomy of educational objectives: The classification of educational goals. Handbook II.: Affective domain. - David Mckay Inc., New York. 196 p.

LeE, J. - Catling, S. (2016): Some perceptions of English geography textbook authors on writing textbooks. - International Research in Geographical and Environmental Education 25. 1. pp. 50-67. https://doi.org/10.1080/10382046.2015.1106204

Manning, P. (2012): Migration in World history (Themes in World history). - Routledge, Abingdon-onThames. 240 p. https://doi.org/10.4324/9780203100707

Pirisi G. - Trócsányi A. (2019): Fejezetek a társadalomföldrajz világából. - PTE TTK Földrajzi és Földtudományi Intézet - Publikon Kiadó, Pécs. 260 p.

Pукетт, J. (2009): Making citizens in the classroom. An urban geography of citizenship education? Urban Studies 46. 4. pp. 803-823. https://doi.org/10.1177/0042098009102130

SARNO, E. (2011): Geography and citizenship education: migrations and pathways of educational research. - Review of International Geographical Education Online 1. 1. pp. 73-83.

Scott, D. - Lawson, H. (2002): Citizenship education and the curriculum. - Greenwood Publishing Group, Connecticut. 190 p.

Valverde, G. A. - Bianchi, L. J. - Wolfe, R. G. - Schmidt, W. H. - Houang, R. T. (2002): According to the book: Using TIMSS to investigate the translation of policy into practice through the world of textbooks. - Springer Netherlands, Dordrecht. 208 p. https://doi.org/10.1007/978-94-007-0844-0 
Vindervoghel, L. J. (2016): Power, identity, and the construction of knowledge in education. - In education 22. 2. pp. 87-97. https://doi.org/10.37119/ojs2016.v22i2.308

YANG, D. - WANG, Z. - XU, D. (2015): A comparison of questions and tasks in geography textbooks before and after curriculum reform in China. - Review of International Geographical Education Online 5. 3. pp. 231-248.

DFE 2014a: The national curriculum in England. Framework document. -https.//assets.publishing.service. gov.uk/government/uploads/system/uploads/attachment_data/file/381344/Master_final_national_ curriculum_28_Nov.pdf [utolsó megtekintés 2020.11.11.]

DFE 2014b: National curriculum in England. geography programmes of study. - Key stages 1 and 2. https.//www.gov.uk/government/publications/national-curriculum-in-england-geography-programmes-of-study [utolsó megtekintés 2020. 11. 11.]

DFE 2014c: National curriculum in England. geography programmes of study. - Key stage 3. https.//www. gov.uk/government/publications/national-curriculum-in-england-geography-programmes-of-study [utolsó megtekintés 2020. 11. 11.]

EEM 2012: 110/2012. (VI. 4.) Korm. rendelet módosításáról. - Magyar Közlöny 2020. 17. pp. 290-446.

EEM 2013: 51/2012. (XII. 21.) EMMI rendelet a kerettantervek kiadásának és jóváhagyásának rendjéről. Magyar Közlöny 2013. 53. pp. 7622-14040.

EEM 2020a: A Kormány 5/2020. (I. 31.) Korm. rendelete a Nemzeti alaptanterv kiadásáról, bevezetéséről és alkalmazásáról szóló 110/2012. (VI. 4.) Korm. rendelet módosításáról. - Magyar Közlöny 2020. 17. pp. 290-447.

EEM 2020b: Kerettanterv. Általános iskola. Földrajz. - https://www.oktatas.hu/kozneveles/kerettantervek/2020_nat/kerettanterv_alt_isk_5_8 [utolsó megtekintés 2020.11. 16.]

EEM 2020c: Kerettanterv. Középiskola. Földrajz. - https://www.oktatas.hu/kozneveles/kerettantervek/2020_nat/kerettanterv_gimn_9_12_evf [utolsó megtekintés 2020. 11. 16.]

Eurostat 2015: European Commission. Demography Report. Publications Office of the European Union. - https.//assets.publishing.service.gov.uk/government/uploads/system/uploads/attachment_data/ file/381344/Master_final_national_curriculum_28_Nov.pdf [utolsó megtekintés 2021. 01. 14.]

OFNS 2011: Immigration Patterns of Non-UK Born Populations in England and Wales in 2011 (PDF). - Office for National Statistics. https://webarchive.nationalarchives.gov.uk/20160107164635/http:// www.ons.gov.uk/ons/dcp171776_346219.pdf [utolsó megtekintés 2021. 01. 20.]

UNESCO (2019): UNESCO International Bureau of Education: Background paper prepared for the 2019 Global education monitoring report: Migration, displacement and education: building bridges, not walls. - https://unesdoc.unescorg/ark:/48223/pf0000266049 [utolsó megtekintés 2020. 02. 26.]

\section{ELEMZETT TANKÖNYVEK}

Alexa P. - Gruber L. - Szőllősy L. - ÜtőNÉ Visi J. (2018): Földrajz 7. - Eszterházy Károly Egyetem Oktatáskutató és Fejlesztő Intézet, Budapest. 207 p.

Arday I. - Buránszkiné Sallai M. - Makádi M. - Nagy B. - Sáriné Gál E. (2018a): Földrajz 9. Eszterházy Károly Egyetem Oktatáskutató és Fejlesztő Intézet, Budapest. 232 p.

Arday I. - Czirfusz M. - Horváth T. (2020): Földrajz tankönyv 9. - Oktatási Hivatal, Budapest. 160 p. 
Arday I. - Köszegi M. - MaKádi M. - SÁriné Gál E. - ÜTőNÉ VISI J. (2018b): Földrajz 10. - Eszterházy Károly Egyetem Oktatáskutató és Fejlesztő Intézet, Budapest. 256 p.

F. Kusztor A. - Makádi M. - Pokк P. - Szőllősy L. (2018): Földrajz 8. - Eszterházy Károly Egyetem Oktatáskutató és Fejlesztő Intézet, Budapest. 191 p.

F. Kusztor A. - NAGy B. (2020): Földrajz tankönyv 9. - Oktatási Hivatal, Budapest. 216 p.

Gallagher, R. - Parish, R. - Williamson, J. (2014): Geog. 1. - Oxford University Press, Oxford. 144 p.

Gallagher, R. - Parish, R. (2014a): Geog. 2. - Oxford University Press, Oxford. 144 p.

Gallagher, R. - Parish, R. (2014b): Geog. 3. - Oxford University Press, Oxford. 144 p. 